INTERNATIONAL JOURNAL OF SYSTEMATIC BACTERIOLOGY

Vol. 18, No. 1 January 1968 pp. 49-50

Copyright 1968, Iowa State University Press

\title{
ON PROPOSING NEW NAMES AND COMBINATIONS
}

\author{
Erwin F. Lessel
}

American Type Culture Collection

Rockville, Maryland, U.S.A.

ABSTRACT. Many we1l-established names of bacterial taxa actually have no standing in nomenclature because the authors of the names did not clearly state that they were introducing new names or combinations at the time of publication. According to Rule $12 \mathrm{c}(3)$ of the International Code of Nomenclature of Bacteria (1966), such names are not validly published. If these names are in common use and if it is desirable to retain them, they may either be conserved by official action of the International Committee on Nomenclature of Bacteria or be reintroduced into the literature by the same or different authors. By calling attention to this often neglected requirement for valid publication of names, it is hoped that in the future new names and combinations will be properly proposed and will not be a source of confusion.

Many commonly used and accepted names of bacteria were not proposed in conformity with the rules of the International Code of Nomenclature of Bacteria because the authors did not clearly indicate that they were proposing new names or combinations; such names have no standing in bacteriological nomenclature. If these names are well established and enjoy popular usage and if, therefore, it is deemed advisable to retain them, they must either be conserved in an Opinion issued by the Judicial Commission of the International Committee on Nomenclature of Bacteria or proposed anew by the same or by different authors. The intent of this paper is to focus attention on this too-often ignored requirement so that new names and combinations will, in the future, be properly introduced into the literature. 
In the International Code of Nomenclature of Bacteria (1966) one of the conditions for the valid publication of a new name or combination is that the author must clearly state that he is proposing a new name or combination. The pertinent rule is $12 c(3)$, which reads as follows:

"A name... which is merely mentioned incidentally is not validly published.

Note ... By 'incidental mention' of a new name or combination is meant mention by an author who does not clearly state that he is proposing a new name or combination."

Generally the above-mentioned requirement is met by an author appending the phrase "species nova" (abbreviation: sp.nov.), "genus novum" (abbreviation: gen. nov.), "nomen novum" (abbreviation: nom. nov.), "combinatio nova" (abbreviation: comb.nov.) or the like after the name or combination he is proposing as new; alternatively the author may make a statement to the effect that he is introducing a new name or combination. If the re is no clear indication that a new name or combination is being proposed, the reader naturally assumes that the name being used either has been proposed previously or is merely being mentioned incidentally with no intention of it being introduced as new.

The reasons for Rule $12 c(3)$ a re obvious: readers should not have to guess at what authors have in mind or are attempting to do; neither should they have to guess at whether the names they are seeing for the first time are being introduced as new or have been published previously elsewhere. The nomenclature of the bacteria will be on a much more stable basis if Rule $12 \mathrm{c}(3)$ is observed.

\section{BIBLIOGRAPHY}

International Code of Nomenclature of Bacteria. 1966. Intern. J. Syst. Bacte riol. 16(4):459-490. 